\title{
Highly Selective DNA-Based Sensor for Lead(II) and Mercury(II) lons
}

\author{
Chi-Wei Liu, ${ }^{\dagger}$ Chih-Ching Huang, ${ }^{\ddagger}$ and Huan-Tsung Chang*,t \\ Department of Chemistry, National Taiwan University, 1, Section 4, Roosevelt Road, Taipei, Taiwan, \\ and Institute of Bioscience and Biotechnology, National Taiwan Ocean University, 2, Beining Road, \\ Jhongjheng District, Keelung, Taiwan
}

We have developed a technique for the highly selective and sensitive detection of $\mathrm{Pb}^{2+}$ and $\mathrm{Hg}^{2+}$ using a thrombin-binding aptamer (TBA) probe labeled with the donor carboxyfluorescein (FAM) and the quencher 4-([4-(dimethylamino)phenyl]azo)benzoic acid (DABCYL) at its 5' and 3' termini, respectively. The TBA has a random coil structure that changes into a G-quartet structure and a hairpin-like structure upon binding $\mathrm{Pb}^{2+}$ and $\mathrm{Hg}^{2+}$ ions, respectively. As a result, the fluorescence decreases through fluorescence resonance energy transfer (FRET) between the fluorophore and quencher. These changes in fluorescence intensity allow the selective detection of $\mathrm{Pb}^{2+}$ and $\mathrm{Hg}^{2+}$ ions at concentrations as low as $300 \mathrm{pM}$ and $5.0 \mathrm{nM}$ using this TBA probe in the presence of phytic acid and a random DNA/NaCN mixture, respectively. The linear correlation existed between the fluorescence intensity and the concentration of $\mathrm{Pb}^{2+}$ and $\mathrm{Hg}^{2+}$ over the range of $0.5-30 \mathrm{nM}\left(R^{2}=0.98\right)$ and $10-200 \mathrm{nM}\left(R^{2}=\right.$ $0.98)$, respectively. To the best of our knowledge, this is the first example of a single DNA-based sensor that allows the detection of both $\mathrm{Hg}^{2+}$ and $\mathrm{Pb}^{2+}$ ions. This simple and cost-effective probe was also applied to separately determine $\mathbf{P b}^{2+}$ in soil samples and spiked $\mathrm{Hg}^{2+}$ in pond samples.

The monitoring of toxic metal ions in aquatic ecosystems is an important issue because these contaminants can have severe effects on human health and the environment. ${ }^{1}$ Lead and mercury are two of the most toxic metallic pollutants; for example, lead can cause renal malfunction and inhibit brain development ${ }^{2}$ and mercury can damage the brain, heart, and kidneys. ${ }^{3}$ Although the powerful technique of inductively coupled plasma mass spectrometry (ICPMS) is used in most current protocols for the detection of these two metal ions, it is rather expensive, complex, and not

* To whom correspondence should be addressed. Phone and Fax: 011-8862-33661171. E-mail: changht@ntu.edu.tw.

${ }^{\dagger}$ National Taiwan University.

* National Taiwan Ocean University.

(1) (a) Campbell, L. M.; Dixon, D. G.; Hecky, R. E. J. Toxicol. Environ. Health, Part B 2003, 6, 325-356. (b) Needleman, H. Annu. Rev. Med. 2004, 55, 209-222.

(2) Needleman, H. L. Human Lead Exposure; CRC Press: Boca Raton, FL, 1991.

(3) (a) Hoyle, I.; Handy, R. D. Aquat. Toxicol. 2005, 72, 147-159. (b) Zalups, R. K. Pharmacol. Rev. 2000, 52, 113-143. suitable for on-site analyses. ${ }^{4}$ The past few years have witnessed great progress in the development of optical and electrochemical techniques for the detection of metal ions. Procedures using small molecules, ${ }^{5}$ DNAzymes, ${ }^{6}$ oligonucleotides, ${ }^{7}$ polymers, ${ }^{8}$ and functional nanoparticles ${ }^{7 \mathrm{c}, 9}$ have all been developed for the selective detection of $\mathrm{Pb}^{2+}$ and/or $\mathrm{Hg}^{2+}$. For example, a fluorescence resonance energy transfer (FRET)-based DNAzyme system was demonstrated for $\mathrm{Pb}^{2+}$ sensing. The sensor was made of FRET between fluorophore and quencher labeled on the DNAzyme (17E) and its substrate, respectively. In the presence of $\mathrm{Pb}^{2+}$, the $17 \mathrm{E}$ catalyzes hydrolytic cleavage of substrate and it turned on the fluorescence for sensing. ${ }^{6}$ For the detection of $\mathrm{Hg}^{2+}$, a colorimetric method was developed using DNAmodified gold nanoparticles (DNA-Au NPs) in aqueous media under a temperature control. In that assay, two types of DNAfunctionalized $\mathrm{Au}$ NPs were prepared, each functionalized with different thiolated-DNA sequences ( $5^{\prime} \mathrm{HS}-\mathrm{C}_{10}-\mathrm{A}_{10}-\mathrm{T}-\mathrm{A}_{10} 3^{\prime}$ and $5^{\prime} \mathrm{HS}-\mathrm{C}_{10}-\mathrm{T}_{10}-\mathrm{T}-\mathrm{T}_{10} 3^{\prime}$ ), which are complementary except for a single thymidine-thymidine mismatch. Each increase in concentration of $1.0 \mu \mathrm{M}$ results in an increase in the melting point by about $5.0^{\circ} \mathrm{C}$, thus providing an easy way of determining $\mathrm{Hg}^{2+}$ concentration. ${ }^{9 \mathrm{~d}}$ Nevertheless, many of these systems have limited practical use because of, for example, poor aqueous solubility, cross-sensitivity toward other metal ions, matrix interference, high cost (e.g., enzymes), complicated processing, the use of unstable molecules (e.g., RNA), or poor sensitivity. Previously, we unveiled a homoge-

(4) Li, Y.; Chen, C.; Li, B.; Sun, J.; Wang, J.; Gao, Y.; Zhao, Y.; Chai, Z. J. Anal. At. Spectrom. 2006, 21, 94-96.

(5) (a) Deo, S.; Godwin, H. A. J. Am. Chem. Soc. 2000, 122, 174-175. (b) Nolan, E. M.; Lippard, S. J. J. Am. Chem. Soc. 2003, 125, 14270-14271. (c) Yang, Y.-K.; Yook, K.-J.; Tae, J. J. Am. Chem. Soc. 2005, 127, 1676016761.

(6) (a) Li, J.; Lu, Y.J. Am. Chem. Soc. 2000, 122, 10466-10467. (b) Liu, J.; Lu, Y. J. Am. Chem. Soc. 2003, 125, 6642-6643. (c) Thomas, J. M.; Ting, R.; Perrin, D. M. Org. Biomol. Chem. 2004, 2, 307-312. (d) Xiao, Y.; Rowe, A. A.; Plaxco, K. W. J. Am. Chem. Soc. 2007, 129, 262-263.

(7) (a) Ono, A.; Togashi, H. Angew. Chem., Int. Ed. 2004, 43, 4300-4302. (b) Chiang, C.-K.; Huang, C. C.; Liu, C.-W.; Chang, H.-T. Anal. Chem. 2008, 80, 3716-3721. (c) Liu, C.-W.; Hsieh, Y.-T.; Huang, C.-C.; Chang, H.-T. Chem. Commun. 2008, 2242-2244. (d) Babkina, S. S.; Ulakhovich, N. A. Anal. Chem. 2005, 77, 5678-5685.

(8) (a) Kim, I.-B.; Bunz, U. H. F. J. Am. Chem. Soc. 2006, 128, 2818-2819. (b) Geary, C. D.; Zudans, I.; Goponenko, A. V.; Asher, S. A.; Weber, S. G. Anal. Chem. 2005, 77, 185-192.

(9) (a) Huang, C.-C.; Chang, H.-T. Chem. Commun. 2007, 12, 1215-1217. (b) Huang, C.-C.; Chang, H.-T. Anal. Chem. 2006, 78, 8332-8338. (c) Huang, C.-C.; Yang, Z.; Lee, K.-H.; Chang, H.-T. Angew. Chem., Int. Ed. 2007, 46, 6824-6828. (d) Lee, J.-S.; Han, M. S.; Mirkin, C. A. Angew. Chem., Int. Ed. 2007, 46, 4093-4096. 


\section{Scheme 1. Cartoon Representation of the Sensing Mechanism of the TBA Probe for the Detection of $\mathrm{Hg}^{2+}$ and $\mathrm{Pb}^{2+}$ Ions}

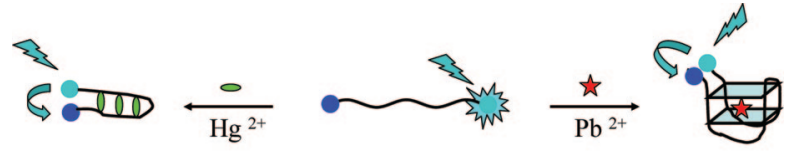

: FAM : DABCYL

$\sim:$ TBA

○: $\mathrm{Hg}^{2+}$

neous assay using the DNA-binding dye TOTO-3 and polythymidine (poly- $\mathrm{T}$ ) to detect $\mathrm{Hg}^{2+}$ through $\mathrm{T}-\mathrm{Hg}^{2+}-\mathrm{T}$ interactions, which induce a conformational change of poly-T into a folded structure that preferably binds TOTO-3. ${ }^{\text {7b }}$ Although such optical (or electrochemical) sensing techniques can be sensitive and selective, they generally allow the detection of only one of the two metal ions.

In this paper we present a technique for the highly selective and sensitive detection of $\mathrm{Pb}^{2+}$ and $\mathrm{Hg}^{2+}$ using a thrombinbinding aptamer (TBA) probe ${ }^{10,11}$ labeled with the donor carboxyfluorescein (FAM) and the quencher 4-([4-(dimethylamino)phenyl]azo) benzoic acid (DABCYL) at its $5^{\prime}$ and $3^{\prime}$ termini, respectively. The sensing mechanism of this probe is based on the change in the DNA strand's conformation from the linear to a folded structure upon binding the metal ions. These conformations exhibit different degrees of FRET between the fluorophore (donor) and quencher (acceptor) at the termini of each DNA probe.

\section{EXPERIMENTAL SECTION}

Chemicals. Acetic acid, 4-(2-hydroxyethyl) piperazine-1-ethanesulfonic acid hemisodium salt (HEPES), phytic acid, sodium cyanide $(\mathrm{NaCN})$, tris (hydroxymethyl)aminomethane (Tris), and all of the metal salts used in this study were purchased from Aldrich (Milwaukee, WI). The TBA probe (Fam-5'-GGTTGGTGTGGTTGG-3'-DABCYL) and the random DNA (5'-ATGTACCGATCACTA-3') were purchased from Integrated DNA Technology, Inc. (Coralville, IA). Montana Soil (SRM 2710) was obtained from the National Institute of Standards and Technology (NIST, Maryland). Milli-Q ultrapure water was used in each experiment. The toxic sodium cyanide was used with caution because it is a potent inhibitor of respiration.

Analysis of Samples. For lead sensing, aliquots $(500 \mu \mathrm{L})$ of $10 \mathrm{mM}$ Tris-acetate ( $\mathrm{pH}$ 7.4) solutions containing the TBA probe $(10 \mathrm{nM}), \mathrm{Pb}^{2+}(0-1.0 \mu \mathrm{M}), \mathrm{NaCN}(100 \mu \mathrm{M})$, and the random blocking DNA $(100 \mathrm{nM})$ were equilibrated at room temperature for 15 min prior to measurement of the fluorescence. In this

(10) (a) Kotch, F. W.; Fettinger, J. C.; Davis, J. T. Org. Lett. 2000, 2, 32773280. (b) Smirnov, I.; Shafer, R. H. J. Mol. Biol. 2000, 296, 1-5. (c) Smirnov, I. V.; Kotch, F. W.; Pickering, I. J.; Davis, J. T.; Shafer, R. H. Biochemistry 2002, 41, 12133-12139.

(11) (a) Katz, S. J. Am. Chem. Soc. 1952, 74, 2238-2245. (b) Yamane, T.; Davidson, N. J. Am. Chem. Soc. 1961, 83, 2599-2607. (c) Miyake, Y.; Togashi, H.; Tashiro, M.; Yamaguchi, H.; Oda, S.; Kudo, M.; Tanaka, Y.; Kondo, Y.; Sawa, R.; Fujimoto, T.; Machinami, T.; Ono, A. J. Am. Chem. Soc. 2006, 128, 2172-2173. (d) Tanaka, Y.; Oda, S.; Yamaguchi, H.; Kondo, Y.; Kojima, C.; Ono, A. J. Am. Chem. Soc. 2007, 129, 244-245.

(12) Test Methods for Evaluating Solid Waste, Physical/Chemical Methods, 3rd ed.; USEPA SW-846, U.S. Government Printing Office: Washington, DC, 1996.

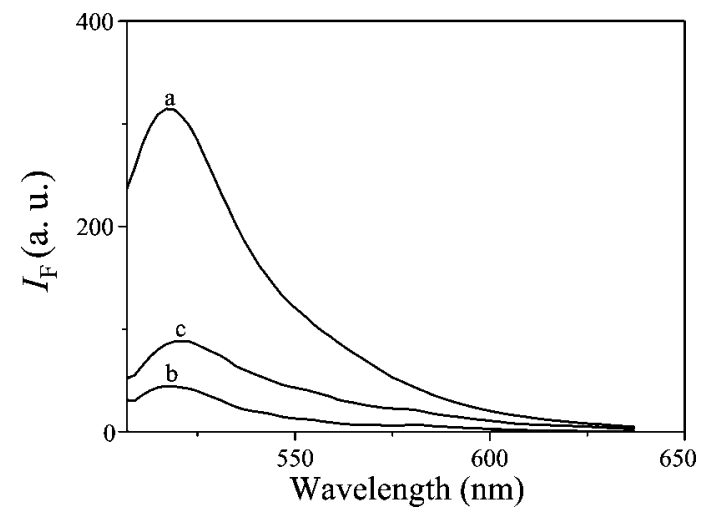

Figure 1. Fluorescence spectra of solutions of (a) TBA probe (10 $\mathrm{nM})$ and (b and c) TBA probe (10 nM) in the presence of (b) $\mathrm{Pb}^{2+}$ (100 nM) and (c) $\mathrm{Hg}^{2+}(500 \mathrm{nM})$. Buffer, $10 \mathrm{mM}$ Tris-acetate $(\mathrm{pH}$ 7.4); excitation wavelength, $475 \mathrm{~nm}$. The fluorescence intensities $\left(I_{\mathrm{F}}\right)$ are plotted in arbitrary units (a. u.).
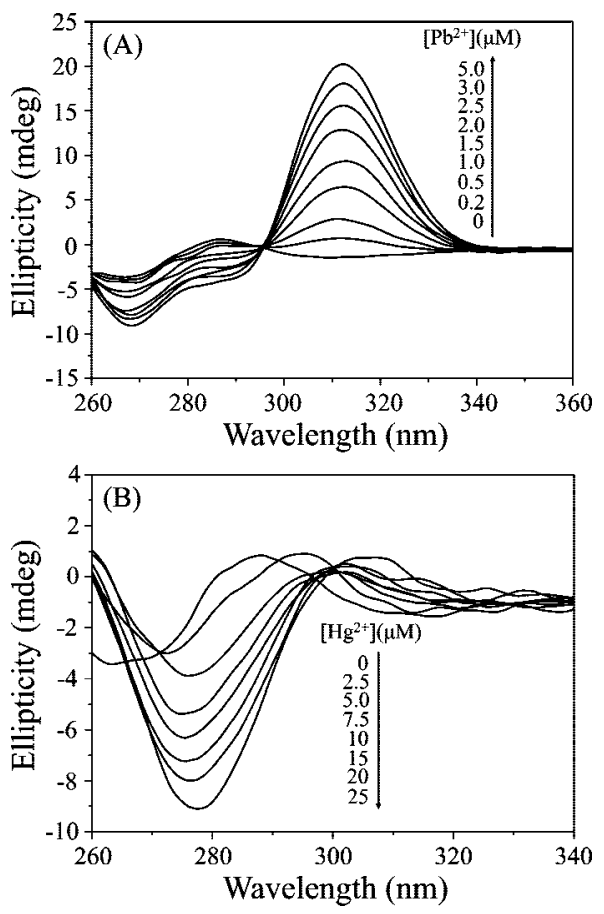

Figure 2. Ellipticity plotted with respect to the $(A) \mathrm{Pb}^{2+}$ ion concentration $(0,0.2,0.5,1.0,1.5,2.0,2.5,3.0$, and $5.0 \mu \mathrm{M})$ and $(B)$ $\mathrm{Hg}^{2+}$ ion concentration $(0,2.5,5.0,7.5,10,15,20$, and $25 \mu \mathrm{M})$. Each sample was prepared in $10 \mathrm{mM}$ Tris-acetate ( $\mathrm{pH} 7.4)$ containing 5.0 $\mu \mathrm{M}$ TBA probe.

paper, the final concentrations of the species are provided. For mercury sensing, aliquots $(500 \mu \mathrm{L})$ of $10 \mathrm{mM}$ Tris-acetate $(\mathrm{pH}$ 7.4) solutions containing the TBA probe $(10 \mathrm{nM}), \mathrm{Hg}^{2+}(0-1.0$ $\mu \mathrm{M})$, and phytic acid (100 $\mu \mathrm{M})$ were equilibrated at room temperature for $15 \mathrm{~min}$ prior to measurement of the fluorescence using a fluorescence spectrophotometers (Cary Eclipse; Varian, California). The fluorescence lifetime of the TBA probe in the absence and presence of the two metal ions were measured using a Edinburgh FL 900 photon-counting system (Edinburgh, U.K.), and then the data were treated by fitting to a biexponential fluorescence decay. Acidic digestion of soil samples $(1 \mathrm{~g})$ was performed according to EPA method 305B. ${ }^{12}$ Aliquots $(50 \mu \mathrm{L})$ of the diluted soil samples $(0.0001 \times)$ were spiked with standard solutions of $\mathrm{Pb}^{2+}$ over the concentration 

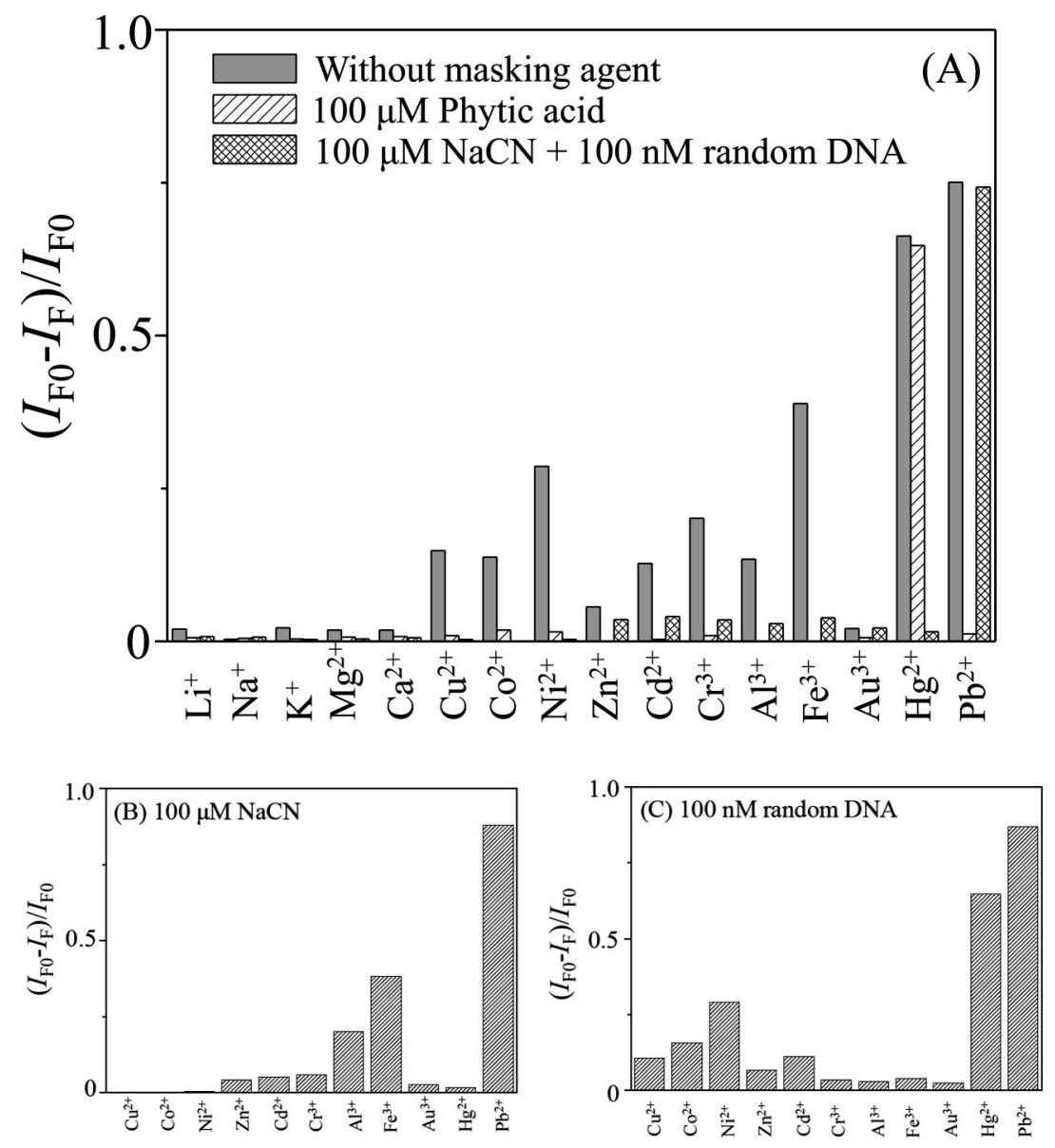

Figure 3. Quenching efficiency $\left(I_{F O}-I_{F}\right) / I_{F 0}$ of the fluorescence intensity $(518 \mathrm{~nm})$ of the probe in the presence of metal ions in the absence and presence of masking agents. (A) Concentrations: $\mathrm{Hg}^{2+}, 1.0 \mu \mathrm{M} ; \mathrm{Pb}^{2+}, 100 \mathrm{nM} ; \mathrm{Li}^{+}$and $\mathrm{Na}^{+}, 100 \mu \mathrm{M} ; \mathrm{K}^{+}, \mathrm{Mg}^{2+}$, and Ca ${ }^{2+}, 10 \mu \mathrm{M}$; other ions, $1.0 \mu \mathrm{M}$. (B and $\mathrm{C})$ metal ions $(1.0 \mu \mathrm{M})$ in the presence of $\mathrm{NaCN}(100 \mu \mathrm{M})$ and random DNA $(100 \mathrm{nM})$, respectively. range of $10-500 \mathrm{nM}$. Prior to analysis, the mixtures were diluted to $500 \mu \mathrm{L}$ with $10 \mathrm{mM}$ Tris-acetate ( $\mathrm{pH}$ 7.4) solution containing the TBA probe $(10 \mathrm{nM}), \mathrm{NaCN}(100 \mu \mathrm{M})$, and the random blocking DNA (100 $\mathrm{nM})$. A water sample collected from a pond on the campus of National Taiwan University was filtered through a $0.2 \mu \mathrm{m}$ membrane. Aliquots of the pond water $(490 \mu \mathrm{L})$ were spiked with standard $\mathrm{Hg}^{2+}$ solutions $(10 \mu \mathrm{L})$ at concentrations over the range of $10-500 \mathrm{nM}$. The spiked samples were then diluted to $1000 \mu \mathrm{L}$ with $10 \mathrm{mM}$ Tris-acetate (pH 7.4, $500 \mu \mathrm{L}$ ) containing $10 \mathrm{nM}$ TBA probe and $100 \mu \mathrm{M}$ phytic acid. The spiked samples were then analyzed separately using ICPMS and the present sensing technique.

\section{RESULTS AND DISCUSSION}

Sensing Strategy. Scheme 1 displays the sensing strategy of the TBA probe toward the two target metal ions $\left(\mathrm{Pb}^{2+}\right.$ and $\left.\mathrm{Hg}^{2+}\right)$. The TBA has a random coil structure that changes into a G-quartet structure ${ }^{10}$ and a hairpin-like structure structure ${ }^{11}$ upon binding $\mathrm{Pb}^{2+}$ and $\mathrm{Hg}^{2+}$ ions, respectively. The TBA consists of nine deoxyguanosine $(\mathrm{G})$ units, which interact specifically with $\mathrm{Pb}^{2+}$ ions to form a G-quadruplex and six $\mathrm{T}$ units, which bind to $\mathrm{Hg}^{2+}$ ions through $\mathrm{T}-\mathrm{Hg}^{2+}-\mathrm{T}$ interactions. As a result of the decreased distance between the donor and acceptor moieties - and, hence, FRET between the FAM and DABCYL units - the fluorescence of FAM in the presence of $\mathrm{Pb}^{2+}$ or $\mathrm{Hg}^{2+}$ is weak. We performed proof-of-concept experiments for the detection of $\mathrm{Pb}^{2+}$ and $\mathrm{Hg}^{2+}$ ions using the TBA probe $(10 \mathrm{nM})$. Curve a in Figure 1 indicates that the fluorescence of the solution containing the TBA probe was strong in the absence of the two metal ions, consistent with the fact that the TBA probe exists in a random coiled structure. After separately adding $\mathrm{Pb}^{2+}(100 \mathrm{nM})$ and $\mathrm{Hg}^{2+}(500 \mathrm{nM})$ to the probe solution, the fluorescence at $518 \mathrm{~nm}$ (excitation at $475 \mathrm{~nm}$ ) decreased to different degrees, as curves $\mathrm{b}$ and $\mathrm{c}$ indicate, respectively. The greater decrease in fluorescence (i.e., greater FRET efficiency) in the presence of $\mathrm{Pb}^{2+}$ than that in the presence of $\mathrm{Hg}^{2+}$ reveals that the donor and acceptor are positioned relatively closer in the G-quartet structure. CD spectra (Figure 2) confirmed the formation of G-quadruplex and hairpin-like structure structures from the TBA probe in the presence of $\mathrm{Pb}^{2+}$ and $\mathrm{Hg}^{2+}$, respectively. ${ }^{10,11}$

In order to further investigate the impacts of $\mathrm{Pb}^{2+}$ and $\mathrm{Hg}^{2+}$ on the fluorescence changes, we compared the lifetimes of the probe in the absence and presence of the metal ions. The lifetimes of the TBA, $\mathrm{Hg}^{2+} / \mathrm{TBA}$, and $\mathrm{Pb}^{2+} / \mathrm{TBA}$ were 2.1, 1.1, and $0.8 \mathrm{~ns}$, respectively. We also compared the fluorescence quenching efficiencies of the probe separately in the presence of $\mathrm{Pb}^{2+}$ and $\mathrm{Hg}^{2+}$ at the same concentration. The quenching efficiencies of $\mathrm{Pb}^{2+}$ and $\mathrm{Hg}^{2+}$ (both at $500 \mathrm{nM}$ ) were $81 \%$ and $66 \%$, respectively. The results reveal that the distance of the two fluorophores in the TBA in the presence of $\mathrm{Pb}^{2+}$ was closer than that of $\mathrm{Hg}^{2+}$. 

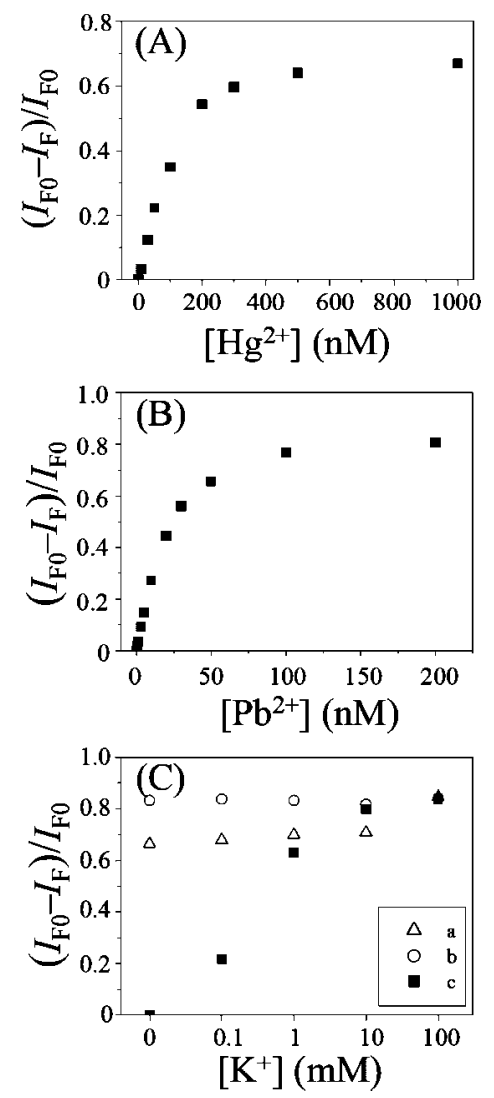

Figure 4. Quenching efficiency plotted with respect to the $(A) \mathrm{Hg}^{2+}$, (B) $\mathrm{Pb}^{2+}$, and (C) $\mathrm{K}^{+}$ion concentrations. The solution contained $\mathrm{K}^{+}$ and interference metal ions $\left(\mathrm{Pb}^{2+}, 100.0 \mathrm{nM} ; \mathrm{Hg}^{2+}, 500.0 \mathrm{nM}\right)$ in the presence of (a) phytic acid $(100 \mu \mathrm{M})$, (b) $\mathrm{NaCN}(100 \mu \mathrm{M})$ and random DNA (100 nM), and (c) phytic acid (100 $\mu \mathrm{M}), \mathrm{NaCN}(100 \mu \mathrm{M})$, and random DNA (100 $\mathrm{nM})$.

Buffer Composition, Masking Agents, and Selectivity. We carefully tested the detection of $\mathrm{Hg}^{2+}$ and $\mathrm{Pb}^{2+}$ using our probe in four different buffer systems (10 mM, pH 7.4), including Tris-acetate, HEPES, sodium acetate, and sodium phosphate. The values of $\left[\left(I_{\mathrm{F} 0}-I_{\mathrm{F}}\right) / I_{\mathrm{F} 0}\right]$ for the solutions buffered with sodium phosphate, HEPES, Tris-acetate, and sodium acetate at $1.0 \mu \mathrm{M} \mathrm{Pb}^{2+}$ were $0.25,0.78,0.80$, and 0.81 , respectively. Herein, $I_{\mathrm{F}}$ and $I_{\mathrm{F} 0}$ represent fluorescence intensity in the presence and absence of the metal ion, respectively. The values of $\left[\left(I_{\mathrm{F} 0}-I_{\mathrm{F}}\right) / I_{\mathrm{F} 0}\right]$ for the solutions buffered with sodium phosphate, HEPES, Tris-acetate, and sodium acetate at 1.0 $\mu \mathrm{M} \mathrm{Hg}^{2+}$ were $0.68,0.66,0.69$, and 0.68 , respectively (data not shown). The sensitivity decreased upon increasing the stability of metal-anion complexes; for example, we obtained lower sensitivity for $\mathrm{Pb}^{2+}$ in phosphate buffer than that in Tris-acetate buffer (formation constants: $\mathrm{p} K_{\mathrm{f}}=43.5$ for $\mathrm{Pb}_{3} \mathrm{~L}_{2}$ (L, phosphate) and $\mathrm{p} K_{\mathrm{f}}=4.1$ for $\mathrm{PbL}_{2}$ (L, acetate; $\mathrm{p} K_{\mathrm{f}}=10.1$ for $\mathrm{HgL}_{2}$ ).

To investigate the selectivity of the TBA probe toward these two metal ions, we added $100 \mathrm{nM} \mathrm{Pb}{ }^{2+}$ and $\mathrm{Hg}^{2+}, 100 \mu \mathrm{M} \mathrm{Li}^{+}$ and $\mathrm{Na}^{+}, 10 \mu \mathrm{M} \mathrm{K}^{+}, \mathrm{Mg}^{2+}$, and $\mathrm{Ca}^{2+}$, and $100 \mathrm{nM} \mathrm{Cu}^{2+}, \mathrm{Co}^{2+}$, $\mathrm{Ni}^{2+}, \mathrm{Zn}^{2+}, \mathrm{Cd}^{2+}, \mathrm{Cr}^{3+}, \mathrm{Al}^{3+}, \mathrm{Fe}^{3+}$, and $\mathrm{Au}^{3+}$ separately into the probe solutions. Only $\mathrm{Pb}^{2+}$ and $\mathrm{Hg}^{2+}$ caused decreases in the fluorescence of FAM (data not shown), revealing that the probe is selective for $\mathrm{Pb}^{2+}$ and $\mathrm{Hg}^{2+}$ ions. High concentrations $(>1.0$ $\mu \mathrm{M})$ of $\mathrm{Cu}^{2+}, \mathrm{Co}^{2+}, \mathrm{Ni}^{2+}, \mathrm{Cd}^{2+}, \mathrm{Cr}^{3+}, \mathrm{Al}^{3+}$, and $\mathrm{Fe}^{3+}$ ions, however, decreased the fluorescence of FAM, leading to false- positive signals (Figure 3A). To overcome this problem, we tested the effects of several masking reagents, including phytic acid, $\mathrm{CN}^{-}$, and a random DNA strand. It is well-known that phosphate ions form stable complexes with several metal ions, including $\mathrm{Fe}^{2+}, \mathrm{Co}^{2+}, \mathrm{Ni}^{2+}, \mathrm{Cu}^{2+}, \mathrm{Zn}^{2+}$, and $\mathrm{Pb}^{2+}$. Thus, we tested the masking capability of phytic acid for the interfering metal ions in our sensing system. Gratifyingly, only $\mathrm{Hg}^{2+}$ caused a decrease in the fluorescence of FAM in the presence of $100 \mu \mathrm{M}$ phytic acid (Figure 3A); i.e., this sensing system is specific to $\mathrm{Hg}^{2+}$. For example, in $10 \mathrm{mM}$ Tris-acetate solution (pH 7.4) containing $100 \mu \mathrm{M}$ phytic acid, the TBA probe provided high selectivity (50-fold or more) toward $\mathrm{Hg}^{2+}$ ions over the other metal ions. To improve the selectivity of the TBA probe toward $\mathrm{Pb}^{2+}$, we added $\mathrm{CN}^{-}$as a masking agent because it forms a much more stable complex with $\mathrm{Hg}^{2+}$ ions ( $\log \beta_{2}=32.8$ ) than with $\mathrm{Pb}^{2+}$ ions. ${ }^{13}$ As indicated in Figure $3 \mathrm{~B}$, the presence of $\mathrm{CN}^{-}$masked the TBA probe toward other ions but not toward $\mathrm{Pb}^{2+}, \mathrm{Al}^{3+}$, or $\mathrm{Fe}^{3+}$. To mask the two trivalent metal ions, we added a random DNA sample (100 nM) having the sequence 5'-ATGTACCGATCACTA-3'. Figure 3C reveals that the random DNA did not mask $\mathrm{Pb}^{2+}$, but it did mask the $\mathrm{Al}^{3+}$ and $\mathrm{Fe}^{3+}$ ions by at least $78 \%$ and $90 \%$, respectively. The random DNA interacted with the two interfering metal ions through electrostatic attractions. The interactions between $\mathrm{Pb}^{2+}$ and the random DNA are much weaker than those with TBA (G-quadruplex). In $10 \mathrm{mM}$ Tris-acetate solution (pH 7.4) containing $100 \mu \mathrm{M} \mathrm{NaCN}$ and $100 \mathrm{nM}$ of the random DNA, the TBA probe provided high selectivity (400-fold or more) toward $\mathrm{Pb}^{2+}$ ions over all of the other tested interference ions (Figure 3A).

Different possible interferences including anions and thiol compounds were also tested. We found that $\mathrm{Cl}^{-}, \mathrm{Br}^{-}, \mathrm{F}^{-}, \mathrm{NO}_{3}{ }^{-}$, $\mathrm{SO}_{4}{ }^{2-}$, and $\mathrm{CO}_{3}{ }^{2-}$ (all sodium salts), respectively, did not interfere the detection of $\mathrm{Pb}^{2+}$ and $\mathrm{Hg}^{2+}$. However, when the concentration of $\mathrm{NaCl}$ increased from 10 to $100 \mathrm{mM}$, the value of $\left[\left(I_{\mathrm{F} 0}-I_{\mathrm{F}}\right) / I_{\mathrm{F} 0}\right]$ for the solution increased from 0.02 to 0.25 , mainly due to the formation of G-quartet under the high-salt conditions. We also found that thiol compounds, such as sodium sulfide, potassium peroxydisulfate, ethanethiol, and thiolurea at high concentrations caused interferences in sensing $\mathrm{Pb}^{2+}$ and $\mathrm{Hg}^{2+}$. The tolerance concentration of these four thiol compounds for detecting $\mathrm{Pb}^{2+}$ and $\mathrm{Hg}^{2+}$ were all 100 and 10 $\mu \mathrm{M}$, respectively. The tolerance concentration is defined by $50 \%$ decreases in the intensity of $\left(I_{\mathrm{F} 0}-I_{\mathrm{F}}\right) / I_{\mathrm{F} 0}$ when the interference is present.

Sensitivity and Application. Under the optimal conditions, we investigated the sensitivity of the TBA probe toward $\mathrm{Hg}^{2+}$ and $\mathrm{Pb}^{2+}$ individually. The fluorescence of FAM decreased upon increasing the concentration of $\mathrm{Hg}^{2+}$ (Figure 4A) or $\mathrm{Pb}^{2+}$ (Figure $4 \mathrm{~B})$. We obtained linear responses of the expression ( $I_{\mathrm{F} 0}$ $\left.-I_{\mathrm{F}}\right) / I_{\mathrm{F} 0}$ against the concentrations of $\mathrm{Hg}^{2+}$ and $\mathrm{Pb}^{2+}$ over the ranges of $10-200 \mathrm{nM}\left(R^{2}=0.98\right)$ and $0.5-30 \mathrm{nM}\left(R^{2}=0.98\right)$, respectively. The TBA probe provided limits of detection (LODs) for $\mathrm{Hg}^{2+}$ and $\mathrm{Pb}^{2+}$ ions (signal-to-noise ratio = 3) of $5.0 \mathrm{nM}$ and $300 \mathrm{pM}$, respectively. Thus, this approach provides a sensitivity toward $\mathrm{Pb}^{2+}$ ions that is more than 1 order of magnitude lower than that reported when using a DNAzyme. ${ }^{6}$

(13) Morel, F. M. M. Principles of Aquatic Chemistry; Wiley: New York, 1983. 
In addition, this TBA probe provides a sensitivity for $\mathrm{Hg}^{2+}$ ions that is comparable to that of a system we reported previously. ${ }^{7 b, 9 \mathrm{c}}$ Our results suggested that this TBA probe would be sensitive for monitoring the levels of $\mathrm{Hg}^{2+}$ and $\mathrm{Pb}^{2+}$ ions in foodstuffs and environmental samples. For example, the U.S. Food and Drug Administration suggests an action level for lead of $2.5 \mu \mathrm{M}$ (500 $\mathrm{ppb}$ ) in products intended for children; the U.S. Environmental Protection Agency permits the maximum level of mercury in drinking water to be $10 \mathrm{nM}(2.0 \mathrm{ppb})$. In addition, we also demonstrated that our sensor provides selective detection of $\mathrm{K}^{+}$in the presence masking agents, phytic acid, $\mathrm{NaCN}$, and random DNA (Figure 4C). The linear range of fluorescence response of our sensor for $\mathrm{K}^{+}$was about $0.1-10 \mathrm{mM}$.

Thus, we used our TBA probe to determine the concentrations of $\mathrm{Pb}^{2+}$ and $\mathrm{Hg}^{2+}$ in soil and pond water samples, respectively. The concentrations of lead determined $(n=5)$ using our new approach and ICPMS were $5.28( \pm 0.07)$ and $5.05( \pm 0.10) \mathrm{mg} /$ $\mathrm{g}$, respectively. The $F$-test value for the correlation between the two methods was 2.04 (the $F$-test value is 6.39 at a $95 \%$ confidence level), suggesting that the two methods did not differ significantly. We obtained a linear correlation $\left(R^{2}=0.97\right)$ between the responses and the concentration of $\mathrm{Hg}^{2+}$ ions spiked into the pond water over the range of $10-200 \mathrm{nM}$. The TBA probe provided recoveries of $95-104 \%$ for these measurements. Neither our probe nor the ICPMS system detected the presence of $\mathrm{Hg}^{2+}$ ions in the pond water sample. These results reveal the practicality of using our TBA probe for the determination of $\mathrm{Hg}^{2+}$ and $\mathrm{Pb}^{2+}$ ions in environmental samples.

\section{CONCLUSION}

In conclusion, we have devised a new assay for the sensitive and selective detection of $\mathrm{Hg}^{2+}$ and $\mathrm{Pb}^{2+}$ ions using an aptamer (TBA) that interacts specifically with thrombin. Changes in the DNA strand's conformation allowed us to readily detect $\mathrm{Hg}^{2+}$ and $\mathrm{Pb}^{2+}$ using this TBA probe in the presence of phytic acid and a random $\mathrm{DNA} / \mathrm{NaCN}$ mixture, respectively. The practicality of this method has been validated by the analyses of soil and water samples. To the best of our knowledge, this is the first example of a single DNA-based sensor that allows the detection of both $\mathrm{Hg}^{2+}$ and $\mathrm{Pb}^{2+}$ ions. The simple, rapid, and cost-effective sensing systems hold great practical for detection of heavy metal ions in real samples.

\section{ACKNOWLEDGMENT}

This study was supported by the National Science Council of Taiwan under contracts NSC-95-2113-M-002-026-MY3, NSC 972627-M-002-010, and NSC 97-2627-M-002-011.

Received for review October 19, 2008. Accepted January 26, 2009.

AC8022185 